\title{
The relationship of body condition and chewing time with body weight, the level of plasma cocaine and amphetamine regulated transcript, leptin and energy metabolites in cows until reaching the lactation peak
}

\author{
Krzysztof Młynek ${ }^{1}$, Beata Głowińska ${ }^{2}$ \\ ${ }^{1}$ Siedlce University of Natural Sciences and Humanities, Faculty of Natural Sciences, \\ Department of Bioengineering and Animal Husbandry, Siedlce, Poland \\ ${ }^{2}$ University of Science and Technology, Faculty of Animal Breeding and Biology, \\ Department of Animal Physiology, Physiotherapy and Nutrition, Bydgoszcz, Poland
}

Received October 22, 2019

Accepted January 28, 2020

\begin{abstract}
This study examined the relationship of body condition and chewing time (CT) with body weight (BW), the level of cocaine-and amphetamine-regulated transcript (CART), leptin and energy metabolites in cows until reaching the lactation peak. The results showed the greatest loss of BW between days 11 and 45 of lactation and a decrease in the body condition score (BCS) until day 75. Chewing time showed an increase from day 45 with the highest values after lactation peak. The CART and leptin concentrations demonstrate a reduction of both indices $(P<0.05)$ between days 11 and 75 . The function of leptin as a factor positively correlating with BW and BCS was found. In the heaviest individuals and those with higher BCS, the blood leptin levels were higher. The results of beta-hydroxybutyrate (BHBA) indicate that cows with the lowest BCS had the most intensive energy transformation. This led to a higher BHBA concentration compared to the cows with high BCS $(P<0.05)$. The obtained results show that CART was most strongly negatively associated with CT $(P<0.05)$. For leptin, the tendency was the opposite and the correlation with CT was not significant. The results suggest that CT may be stronger regulated by CART, which has anorectic properties, than by appetite inhibiting leptin. Significant decrease of body condition during lactation is a great problem for dairy farmers. The explanation of the issue of the participation of CART and leptin in the regulation of body's energy homeostasis may therefore be of importance for milk production.
\end{abstract}

Blood indicators, energy balance, milk production, neuropeptide

Metabolic profile indicators are of great importance for early identification of energy metabolism disturbances in cows. Knowledge of the processes regulating the secretion of milk and physiological factors determining fat tissue accumulation is particularly important in high-yielding cows. In practice, despite the use of high-energy diets, a strongly negative energy balance is observed in these animals until lactation peak is reached. In addition, it is accompanied by reduced dry matter (DM) intake which increases the energy deficit even more, and insufficient coverage of the organism's nutrient needs (Ellis et al. 2006; Wathes et al. 2007; Leblanc 2010). In response to negative DM intake, a strong loss of the body condition score (BCS) is commonly observed (Patton et al. 2007). This situation results in a decrease in the level of leptin in the blood and the activation of energy reserves accumulated in fat (Vargová et al. 2015). It can also negatively affect the functions of many other organs (Roche et al. 2007). Leptin is the main regulator of feed intake, an inhibitor of lipogenesis and the main stimulator of lipolysis (Ahima and Flier 2000; Ingvartsen and Boisclair 2001; Chilliard et al. 2005). However, leptin functions may be somewhat attenuated by anorectic agents, including the cocaine- and amphetamineregulated transcript (CART). It is considered as factor affecting the suppression of appetite (Brady et al. 1990; Hwang and Guntz 1997). By regulating appetite, CART has an effect on feed intake and chewing time (CT) which determine the rumen metabolism and

Address for correspondence:

Beata Głowińska

Department of Animal Physiology, Physiotherapy and Nutrition

University of Science and Technology

Mazowiecka 28, 85084 Bydgoszcz, Poland 
the energy balance in cattle (Hunter et al. 2004; Nikkhan 2011). One of the sources of CART are neurosecretory cells (DNES) in the hypothalamus and other tissues (e.g. gastrointestinal tract) that release CART into the blood (Kasacka and Piotrowska 2012; Janiuk et al. 2013). In the hypothalamus the presence of CART has been observed in nuclei responsible for nutrition or motor activity and also in the regions of the central nervous system considered to be the most important in the regulation of the cardiovascular system (Koylu et al. 1998; Kasacka and Piotrowska 2012). Peptide has also been localized in the peripheral nervous system (Wierup et al. 2007), among others locations in the nerve ganglia of the pyloric part of the abomasum in cattle. This presence has been confirmed by the studies conducted by Młynek et al. (2015). According to Elias et al. (2001), the location of CART-containing structures which are in the vicinity of leptin secreting receptors, may inhibit the transduction of the leptin signal, therefore, the excessive mobilization of fat reserves in cows during energy deficit periods may also increase the activity of the areas releasing CART (Kristensen et al. 1998; Wang et al. 1999).

Most reliable indicators of the cow's energy status are beta-hydroxybutyrate (BHBA) and glucose concentrations. The body fat mobilization in high-yielding cows is associated with non-esterified fatty acids production, which are esterified into triacylglycerols and BHBA (Sumner and McNamara 2007). According to Stengärde et al. (2008), the concentration of these parameters is in high correlation with the amount of deposited fat (BCS) during the peripartal period.

The aim of this study was to examine the relationship of body condition and CT with body weight (BW), the level of CART, leptin and energy metabolites in high-yielding dairy cows until reaching the lactation peak. The experimental hypothesis was that the concentrations of CART, leptin, glucose and BHBA are correlated with cow's fat deposition and chewing activity, and are dependent on the lactation phase.

\section{Materials and Methods}

Animals, housing, and feeding

The study was conducted under a research protocol approved by the Third Local Ethics Committee in Warsaw, No. 70/2013 of 19 December 2013.

The animals were obtained from a private farm located in eastern Mazovia. The experiment was carried out in 69 Holstein-Friesian (HF) cows whose mean production age was 2.5 lactations $( \pm 0.9)$. The animals did not show any disease symptoms (ketosis, acidosis, perinatal diseases). In the analysed period of lactation, 5 post partum phases were distinguished: the first week ( 1 to 7 days), the second week ( 8 to 14 days), the second month ( 31 to 60 days), the third month (61 to 90 days) and the fourth month (91 to 120 days). The material for evaluation of the indices in the individual phases was acquired on days: $4 \pm 1.2,11 \pm 2.1,45 \pm 3.5,75 \pm 4.4$ and $105 \pm 5.3$ on average. About 24 $\mathrm{h}$ after calving, the cows were transferred to the same production group. The animals were kept in a free-stall barn with separate lying areas where they had free access to water. The cows were milked by an A3 milking robot (Lely, Maassluis, the Netherlands) and fed in concentrated feeding stations. A Juno automatic feed push-up robot (Lely) was used at the feed bunk. The average number of milkings was $2.5 \pm 1.2$ per day. The roughage was prepared in a feed wagon and given ad libitum $(5: 30 \mathrm{~h}$ and 17:30 $\mathrm{h})$. The cows were fed using the total mixed ration (TMR) system in order to ensure the proper amount of all nutrients (Table 1). The nutritional value of the feed was determined each time after the silos with silage were opened. The diet was formulated to meet or exceed the nutrient requirements for a lactating HF breed weighing $550 \mathrm{~kg}$, according to the INRA feeding standards with the use of INRAtion Software for Ruminant Diet Calculation, version 2.03 (DJ Group, Krakow, Poland). The diet in each period of the experiment was determined based on the production of milk standardized for $4.0 \%$ fat and $3.5 \%$ protein. The average dry matter intake was determined for the group in each period of the experiment. The dry matter intake balance was calculated on the basis of the difference between the weight of given feed and the leavings $(\mathrm{kg})$. Checks were carried out every few days during the experiment. The particle size in the feed was defined according to Heinrichs' procedure (2013). Particle size distribution was as follows: $19 \mathrm{~mm}$ : 21.5 to $23.7 \% \pm 3.35 ; 8 \mathrm{~mm}: 27.8$ to $28.2 \% \pm 2.16 ; 4 \mathrm{~mm}: 8.7$ to $9.05 \% \pm 1.59$; Pan: 39.5 to $41.8 \% \pm 1.54$. The data are mean values for all lactation periods.

\section{Production and body condition monitoring}

Transponders were used for identification of the cows in the T4C 3.7 (Lely) management software. The chewing time was measured using noseband-sensor halters (QWES-HR system; Lely). The time of feed intake (head down) was not included in the CT. The body weight was determined using a weighing platform mounted on 
Table 1. Components of diets ( $\mathrm{kg} / \mathrm{head} / \mathrm{day})$.

\begin{tabular}{lccccc}
\hline Component & \multicolumn{5}{c}{ Mean time of post partum (day) } \\
\cline { 2 - 6 } & 4 & 11 & 45 & 75 & 105 \\
\hline Corn silage & 30 & 30 & 30 & 30 & 30 \\
Grass silage & 15 & 15 & 15 & 15 & 15 \\
Wheat meal & 3.0 & 3.0 & 2.5 & 2.0 & 1.5 \\
Full-fat soybean meal & 1.0 & 1.0 & 1.0 & 1.0 & 1.0 \\
Full-fat rapeseed meal & 1.0 & 1.0 & 1.0 & 1.0 & 1.0 \\
Dried molasses beet pulp & 4.0 & 4.0 & 3.5 & 2.0 & 1.0 \\
Post-extraction soybean cake & 2.5 & 2.5 & 2.0 & - & - \\
Post-extraction rapeseed cake & 2.0 & 2.0 & 1.5 & - & - \\
DM (\%) & 45.4 & 45.4 & 44.9 & 43.5 & 40.6 \\
CP (\% of DM) & 14.35 & 14.42 & 14.5 & 12.6 & 12.05 \\
NEL (MJ/kg) & 4.54 & 4.56 & 4.98 & 6.32 & 6.07 \\
ADF (\% of DM) & 22 & 21 & 20 & 21 & 22 \\
NDF (\% of DM) & 29 & 28 & 29 & 29 & 30 \\
DMI (kg/d) & 17.5 & 18.1 & 20.89 & 21.5 & 22.4 \\
Energy requirement (MJ NEL) & 124.0 & 132.4 & 142.2 & 151.1 & 138.7 \\
Energy input (MJ NEL) & 95.2 & 108.6 & 124.5 & 141.0 & 137.9 \\
Energy balance (MJ NEL) & -28.2 & -23.8 & -17.7 & -3.34 & -0.8 \\
\hline
\end{tabular}

DM - dry matter; CP - crude protein; NEL - netto energy for lactation; ADF - acid detergent fiber; NDF - neutral detergent fibre; DMI - dry matter intake

the floor of the milking stall (A3 sensor system; Lely). Calibration of the devices was performed at the beginning of the experiment. In each period of the experiment, the mean values of the analysed factors (BW, CT and milk yield) were determined based on the data collected individually from each cow. The cows were evaluated for the amount of deposited fat using BCS (Edmonson et al. 1989; Metzner et al. 1993) in the range of 1 to 5 points $(1$ point $=$ emaciated; 5 point $=$ obese $)$. The BCS was the mean of the ratings performed by two independent persons, carried out at the beginning of each period. For the purposes of the experiment, the division of animals into classes I, II and III in relation to the BCS and CT was made by analysing the normal distribution of a given factor and using general discriminant analysis (GDA) taking into account the analysed lactation phases $(P<0.05)$.

\section{Blood collection and storage}

The blood samples were acquired in the morning, on days 4,11, 45, 75 and 105 post partum, about $1 \mathrm{~h}$ before feeding and about $2 \mathrm{~h}$ before milking. Blood was collected from the abdominal vein using a 10-ml vacuum tube with sodium heparin, and a $1.6 \times 3.8-\mathrm{mm}$ needle (Medlab-Products Ltd., Raszyn, Poland). After collection, all blood samples were transported to the laboratory on ice (the time did not exceed $3 \mathrm{~h}$ ). Plasma was harvested after centrifugation at $2,000 \times \mathrm{g}$ for $15 \mathrm{~min}$ at $4{ }^{\circ} \mathrm{C}$ and frozen at $-75^{\circ} \mathrm{C}$. The plasma samples were analysed for the levels of CART and the leptin hormone using the bovine specific ELISA kit (EIAab, Wuhan, China). In the ELISA, fragment 55-102 of CART was recognized. Blood for the determination of glucose was collected into tubes with sodium fluoride and sodium heparin (Medlab-Products Ltd.). The glucose content in the blood was measured using original Randox kits (Randox Laboratories Ltd, Crumlin, UK) and a UV-Vis spectrophotometer (Varian Inc., Palo Alto, CA, USA). Samples to determine BHBA were centrifuged at $1,500 \times g$ at $4{ }^{\circ} \mathrm{C}$ for $20 \mathrm{~min}$. The supernatant was collected and stored at $-75^{\circ} \mathrm{C}$ until it was analysed for BHBA using original Randox kits (Randox Laboratories Ltd.) and a UV-Vis spectrophotometer (Varian Inc.). All samples were measured in triplicate.

\section{Statistical analysis}

The data were subjected to statistical analysis using the Statistica 13.1 program (TIBCO Software Inc., USA). The ANOVA model with repeated measurements was applied, taking into account one of the studied factors: post partum time, BCS, or $\mathrm{CT}$. A division into study groups within the factors was made using a multidimensional discrimination model. The analysis was based on the mixed linear model taking into account post partum time as a permanent effect (covariance type AR) and an animal as a random effect. The tables present the weighted mean values of the analysed indicators, standard error of the mean (SEM), and the $P$ value. Differences between means were tested by Tukey's method (the level of significance set at 5\%). Pearson's correlation coefficients were calculated for BCS and CT, including BW and blood parameters $(P<0.05)$. 


\section{Results}

The analysis of indicators characterizing the body condition shows that up to day 45 of lactation, there was a gradual decrease in the BW (Table 2). However, the greatest loss was observed between days 11 and 45 post partum. On the other hand, BCS decreased until day 75 of lactation. At the same time, in the period from 4 to 75 days there was an increase in the daily milk production by an average of $11.7 \mathrm{~kg}$. During this period, the cows most often reached the peak milk yield. After this period, the animal's condition began to improve, as evidenced by the increasing values of BW and BCS. The CT data obtained in the analysed post partum phases (Table 2) showed a gradual increase of this index from day 45 of lactation with the greatest values usually achieved after the lactation peak (day 105). The CART and leptin concentrations presented in Table 2 demonstrate a significant reduction of both indices between days 11 and 75 post partum $(P<0.05)$. During this period, a systematic increase in daily milk production was noted. There was no significant effect of the analysed lactation phases on post partum glucose values $(P=0.146)$. As for BHBA, it was shown that its concentration in the cows' blood was relatively higher in the period preceding the lactation peak (day 75 post partum). After this time, the value of this parameter clearly decreased by $0.228 \mathrm{mmol} \cdot \mathrm{l}^{-1}$ on average $(P<0.05)$.

Table 2. Production and body condition indicators, chewing time and blood parameters in cows during lactation.

\begin{tabular}{|c|c|c|c|c|c|c|c|}
\hline \multirow[b]{2}{*}{ Indicator } & \multicolumn{5}{|c|}{ Mean time of post partum (day) } & \multirow[b]{2}{*}{ SEM } & \multirow[b]{2}{*}{$P<$} \\
\hline & $\begin{array}{c}4 \\
(n=69)\end{array}$ & $\begin{array}{c}11 \\
(n=69)\end{array}$ & $\begin{array}{c}45 \\
(n=69)\end{array}$ & $\begin{array}{c}75 \\
(n=69)\end{array}$ & $\begin{array}{c}105 \\
(n=69)\end{array}$ & & \\
\hline BW (kg) & $544^{\mathrm{a}}$ & $539^{\mathrm{bc}}$ & $526^{\mathrm{b}}$ & $533^{\mathrm{b}}$ & $541^{\mathrm{c}}$ & 2.6 & 0.001 \\
\hline Milk production (1/d) & $25.4^{\mathrm{a}}$ & $31.2^{\mathrm{b}}$ & $34.3^{\mathrm{c}}$ & $37.1^{\mathrm{d}}$ & $33.2^{\mathrm{cb}}$ & 2.1 & 0.004 \\
\hline BCS (point) & $2.5^{\mathrm{a}}$ & $2.1^{\mathrm{b}}$ & $2.0^{\mathrm{b}}$ & $1.7^{\mathrm{b}}$ & $2.3^{\mathrm{c}}$ & 0.6 & 0.012 \\
\hline $\mathrm{CT}(\mathrm{min} / \mathrm{d})$ & $759^{a}$ & $752^{\mathrm{a}}$ & $769^{b}$ & $779^{c}$ & $788^{\mathrm{d}}$ & 3.9 & 0.008 \\
\hline \multicolumn{8}{|l|}{ Blood indicator: } \\
\hline CART $\left(\mathrm{ng} \cdot \mathrm{ml}^{-1}\right)$ & $1.296^{\mathrm{a}}$ & $1.240^{\mathrm{a}}$ & $0.961^{\mathrm{b}}$ & $0.711^{\mathrm{c}}$ & $0.712^{\mathrm{c}}$ & 0.021 & 0.021 \\
\hline Leptin $\left(\mathrm{ng} \cdot \mathrm{ml}^{-1}\right)$ & $3.392^{\mathrm{a}}$ & $3.414^{\mathrm{a}}$ & $3.301^{\mathrm{b}}$ & $3.226^{\mathrm{c}}$ & $3.204^{\mathrm{c}}$ & 0.047 & 0.016 \\
\hline Glucose $\left(\mathrm{mmol} \cdot \mathrm{l}^{-1}\right)$ & $3.443^{\mathrm{a}}$ & $2.441^{\mathrm{b}}$ & $2.719^{\mathrm{b}}$ & $2.939^{b}$ & $3.059^{\mathrm{c}}$ & 0.035 & 0.146 \\
\hline $\operatorname{BHBA}\left(\mathrm{mmol} \cdot \mathrm{l}^{-1}\right)$ & $0.884^{\mathrm{a}}$ & $0.977^{\mathrm{a}}$ & $0.846^{\mathrm{b}}$ & $0.807^{\mathrm{b}}$ & $0.579^{c}$ & 0.029 & 0.002 \\
\hline
\end{tabular}

SEM - standard error of the mean; BW - body weight; BCS - body condition score; CT- chewing time; CART - cocaine- and amphetamine-regulated transcript; BHBA - beta-hydroxybutyrate; ${ }^{\mathrm{a}, \mathrm{b}, \mathrm{c}, \mathrm{d}}$ - means in the row with different superscripts differ significantly $(P<0.05)$

Table 3 shows the summary of the BW results in the tested cows, the level of peptides involved in energy metabolism, the concentration of glucose and BHBA depending on the $\mathrm{BCS}$. In the BCS classes (I to III), the mean values ranged from 1.89 to 3.57 points. These data indicate that in the heaviest individuals and those with higher BCS, the blood CART concentrations were lower and leptin levels were higher. The mean CART concentration in the blood plasma of cows ranked in the first BCS class $(<2.4)$ was $1.148 \mathrm{ng} \cdot \mathrm{ml}^{-1}$. In comparison, the blood of individuals with a BCS higher than 2.4 points contained by $0.453 \mathrm{ng} \cdot \mathrm{ml}^{-1}$ lower mean CART concentration $(P<0.05)$. The blood of individuals ranking in the class $>2.4$ points (II and III) was characterized by a higher content of leptin $(P<0.05)$. The glucose values differed significantly in BCS classes II and III in comparison with class I. These tendencies of changes of the analysed indicators depending on the BCS (Table 3) were confirmed by the values of the correlation coefficient presented in Table 4. The results of the BHBA concentration in the blood plasma shown in Table 3 
Table 3. Pearson's correlation coefficients for BCS with BW and blood indicators.

\begin{tabular}{|c|c|c|c|c|c|c|}
\hline \multirow[b]{2}{*}{ Indicator } & \multicolumn{3}{|c|}{ BCS (point) } & \multirow[b]{2}{*}{ SEM } & \multirow[b]{2}{*}{$P<$} & \multirow{2}{*}{$\begin{array}{c}\text { Correlation } \\
\text { coefficient } \\
\text { BCS } \times\end{array}$} \\
\hline & $\begin{array}{c}\mathrm{I}<2.4 \\
(\mathrm{n}=19)\end{array}$ & $\begin{array}{c}\text { II } 2.4 \text { to } 3.4 \\
(\mathrm{n}=38)\end{array}$ & $\begin{array}{l}\text { III }>3.4 \\
(n=12)\end{array}$ & & & \\
\hline Mean day of lactation & 38 & 78 & 91 & 4.97 & 0.021 & $0.318^{*}$ \\
\hline BCS (point) & $1.89^{\mathrm{a}}$ & $2.83^{\mathrm{b}}$ & $3.57^{\mathrm{c}}$ & 0.03 & 0.000 & - \\
\hline BW (kg) & $531^{\mathrm{a}}$ & $537^{\mathrm{b}}$ & $542^{\mathrm{b}}$ & 4.60 & 0.024 & $0.376^{*}$ \\
\hline \multicolumn{7}{|l|}{ Blood indicator: } \\
\hline CART $\left(\mathrm{ng} \cdot \mathrm{ml}^{-1}\right)$ & $1.148^{\mathrm{a}}$ & $0.712^{b}$ & $0.679^{b}$ & 0.021 & 0.008 & $-0.520 *$ \\
\hline Leptin $\left(\mathrm{ng} \cdot \mathrm{ml}^{-1}\right)$ & $3.254^{\mathrm{a}}$ & $3.335^{\mathrm{b}}$ & $3.376^{\mathrm{c}}$ & 0.033 & 0.002 & $0.359^{*}$ \\
\hline Glucose $\left(\mathrm{mmol} \cdot \mathrm{l}^{-1}\right)$ & $2.541^{\mathrm{a}}$ & $3.024^{b}$ & $3.204^{\mathrm{b}}$ & 0.035 & 0.015 & $0.485^{*}$ \\
\hline $\operatorname{BHBA}\left(\mathrm{mmol} \cdot \mathrm{l}^{-1}\right)$ & $0.873^{\mathrm{a}}$ & $0.736^{\mathrm{b}}$ & $0.619^{c}$ & 0.013 & 0.000 & $-0.357^{*}$ \\
\hline
\end{tabular}

BCS - body condition score; SEM - standard error of the mean; BW - body weight; CART - cocaine- and amphetamine-regulated transcript; BHBA - beta-hydroxybutyrate; ${ }^{a}, \mathrm{~b}, \mathrm{c}$ - means in the row with different superscripts differ significantly $(P<0.05) ; * P<0.05$

Table 4. Pearson's correlation coefficients for CT with BW and blood indicators.

\begin{tabular}{|c|c|c|c|c|c|c|}
\hline \multirow[b]{2}{*}{ Indicator } & \multicolumn{3}{|c|}{ CT (min/day) } & \multirow[b]{2}{*}{ SEM } & \multirow[b]{2}{*}{$P<$} & \multirow{2}{*}{$\begin{array}{c}\text { Correlation } \\
\text { coefficient } \\
\text { CT } \times\end{array}$} \\
\hline & $\begin{array}{c}\mathrm{I} \\
(\mathrm{n}=15)\end{array}$ & $\begin{array}{c}\text { II } \\
(\mathrm{n}=30)\end{array}$ & $\begin{array}{c}\text { III } \\
(\mathrm{n}=24)\end{array}$ & & & \\
\hline Mean day of lactation & 34 & 62 & 87 & 5.48 & 0.019 & $0.267^{*}$ \\
\hline $\mathrm{CT}(\mathrm{min} / \mathrm{d})$ & $695^{\mathrm{a}}$ & $774^{\mathrm{b}}$ & $844^{c}$ & 3.9 & 0.000 & - \\
\hline BW (kg) & $527^{\mathrm{a}}$ & $534^{\mathrm{b}}$ & $549^{\mathrm{c}}$ & 2.6 & 0.007 & $0.338^{*}$ \\
\hline \multicolumn{7}{|l|}{ Blood indicator: } \\
\hline CART $\left(\mathrm{ng} \cdot \mathrm{ml}^{-1}\right)$ & $1.352^{\mathrm{a}}$ & $0.954^{\mathrm{b}}$ & $0.686^{c}$ & 0.021 & 0.000 & $-0.667 *$ \\
\hline Leptin $\left(\mathrm{ng} \cdot \mathrm{ml}^{-1}\right)$ & $3.127^{\mathrm{a}}$ & $3.210^{\mathrm{a}}$ & $3.419^{\mathrm{b}}$ & 0.047 & 0.025 & 0.242 \\
\hline Glucose $\left(\mathrm{mmol} \cdot \mathrm{l}^{-1}\right)$ & $2.313^{\mathrm{a}}$ & $2.747^{\mathrm{b}}$ & $3.114^{\mathrm{c}}$ & 0.035 & 0.005 & $0.482 *$ \\
\hline $\mathrm{BHBA}\left(\mathrm{mmol} \cdot \mathrm{l}^{-1}\right)$ & $0.904^{\mathrm{a}}$ & $0.798^{\mathrm{b}}$ & $0.764^{b}$ & 0.052 & 0.005 & -0.201 \\
\hline
\end{tabular}

CT - chewing time; SEM - standard error of the mean; BW - body weight; CART - cocaine- and amphetamineregulated transcript; BHBA - beta-hydroxybutyrate; ${ }^{\text {a,b,c }}$ - means in the row with different superscripts differ significantly $(P<0.05) ; * P<0.05$

indicate that cows with the lowest BCS (1.89 points) more frequently had the most intensive energy transformation. This led to a higher BHBA concentration compared to cows in good condition and a consequently high BCS $(P<0.05)$. A decreasing tendency of BHBA serum concentration, which was observed in our studies with the simultaneous increase in BCS, was confirmed by the value of the correlation coefficient $(P<0.05$, Table 3). Table 4 presents the concentrations of these compounds depending on CT. Longer CT $(P<0.05)$ was observed in individuals with higher BW. This was confirmed by the value of correlation coefficient $(P<0.05)$. The data in Table 4 show that CART was most strongly negatively associated with $\mathrm{CT}(P<0.05)$. There was a clear tendency for the value of this parameter to decrease with the prolongation of $\mathrm{CT}(P<0.05)$. The differences of CART between the CT classes ranged from 0.389 to $0.268(P<0.05)$. The level of glucose in individuals with a longer CT was higher, which was confirmed by the differences between the analysed CT classes $(P<0.05)$ and the value of the correlation coefficient $(P<0.05)$. The results of the negative correlation between the concentration of 
CART and leptin in the blood are shown in Fig. 1 (Plate IV) $(P<0.05)$. Fig. 2 (Plate IV) and Fig. 3 (Plate V) demonstrating the relationship between the glucose concentration in the blood show a stronger link with CART concentration (Fig. 2) than with glucose and leptin concentrations (Fig. 3).

\section{Discussion}

The function of leptin as a factor positively correlating with BW and the amount of fat accumulated in the body, was demonstrated in the studies by Daniel et al. (2002) and Delavaud et al. (2002). A higher blood leptin level in the heaviest individuals with higher BCS in the present experiment also coincides with the results reported by Reist et al. (2003) and Vargová et al. (2015). In contrast, Holtenius et al. (2003) did not find a positive correlation between BCS and blood leptin concentration.

As for BHBA, which was used to describe lipid metabolism in the body, the concentration in the blood plasma indicates that cows with the weaker body condition more frequently had the most intensive energy transformation. This led to the higher BHBA level compared to cows in good condition. A similar relationship was demonstrated in the study by Samanć et al. (2011). The decreasing tendency of BHBA serum concentration with a simultaneous increase in BCS is in line with the results obtained by Kessel et al. (2008) and Vargová et al. (2015).

Given the peculiarity of cattle digestion and the increasing energy deficit during the first weeks of lactation, high yielding cows should devote the most time to chewing food. This stimulates the functions of the digestive tract and increases the use of ingredients from feed. The effect of CT on energy metabolism may be manifested, among others, by changes in the concentration of glucose and BHBA in the blood. The level of these parameters is, however, indirectly dependent on peptides and hormones, such as CART and leptin, which are involved in the regulation of lipid metabolism, and can significantly regulate the feeling of satiety (Ahima and Flier 2000; Ingvartsen and Boisclair 2001; Chelikani et al. 2004). The strongly negatively correlation between CART and CT observed in this study can partially explain the presence of CART in the nerve ganglia of the pyloric part of the abomasum, which was demonstrated in earlier studies (Młynek et al. 2015). The higher level of glucose in cows with a longer chewing time appears to be similar to that observed in earlier studies, which found that the quantity and quality of feed had an impact on the process of chewing and determined the level of glucose in the blood of lactating cows (Frohli and Blum 1988; McGuire et al. 1995; Chelikani et al. 2004). The stability of the glucose level in the body, which is one of the most important energy management substrates, is an indicator of body metabolic homeostasis. In the present experiment, the blood glucose concentration shows a stronger correlation with the CART concentration than with the leptin concentration. Thus, it can be hypothesized that by shortening the duration of the processes related to food intake and CT, CART delays the release of glucose into blood. This results in a lower glucose concentration in the final energy metabolism balance felt as an energy deficit and induction of the mechanisms of lipid transformation in which leptin, released by adipocytes, is involved.

The negative correlation between the concentration of CART and leptin in the blood obtained in this study suggests that the functions of this anorectic neuropeptide may have an antagonizing effect on leptin signal transduction. This may partly explain the stronger and negative correlation between CART and the BCS and the weaker correlation between leptin and this index as well as the correlation with CT. These results are in line with the outcomes of the study conducted by Elias et al. (2001).

This study confirmed that both CART and leptin levels are strongly but oppositely correlated with a cow's fat deposition and are dependent on the lactation phase. In the case 
of CART, the correlation with BCS is strongly negative and the same relationship applies to BHBA. For leptin, the correlation with BCS is positive and the same type of correlation occurs for glucose concentration. The results obtained in the present experiment suggest that chewing may be more strongly regulated by CART which has anorectic properties, than by appetite inhibiting leptin, but to fully confirm this conclusion, it is necessary to conduct further research in this direction. The problem for dairy farmers is the reduced dry matter intake of cows until the peak of lactation is reached. This results in a negative energy balance and excessive activation of fat reserves which causes a significant decrease of body condition. The explanation of the issue of the participation of CART and leptin in the regulation of the body's energy homeostasis may therefore be of great importance for milk production.

\section{References}

Ahima RS, Flier JS 2000: Leptin. Annu Rev Physiol 62: 413-437

Brady LS, Smith MA, Gold PW, Herkenham H 1990: Altered expression of hypothalamic neuropeptide mRNAs in food restricted and food deprived rats. Neuroendocrinology 52: 441-447

Chelikani PK, Ambrose JD, Keisler DH, Kennelly JJ 2004: Effect of short-term fasting on plasma concentrations of leptin and other hormones and metabolites in dairy cattle. Domest Anim Endocrinol 26: 33-48

Chilliard Y, Delavaud C, Bonnet M 2005: Leptin expression in ruminants: Nutritional and physiological regulations in relation with energy metabolism. Domest Anim Endocrin 29: 3-22

Daniel JA, Whitlock BK, Baker JA, Steele B, Morrison CD, Keisler DH, Sartin JL 2002: Effect of body fat mass and nutritional status on 24-h leptin profiles in ewes. J Anim Sci 80: 1083-1089

Delavaud C, Ferlay A, Faulconnier Y, Bocquier F, Kann G, Chilliard Y 2002: Plasma leptin concentration in adult cattle: effect of breed, adiposity, feeding level, and meal intake. Anim Sci 80: 1317-1328

Edmonson AJ, Lean IJ, Weaver LD, Farver T, Webster G 1989: A body condition scoring chart for Holstein dairy cows. J Dairy Sci 72: 68-78

Elias CF, Lee CE, Kelly JF, Ahima RS, Kuhar M, Saper CB, Elmquist JK 2001: Characterization of CART neurons in the rat and human hypothalamus. J Comp Neurol 432: 1-19

Ellis JL, Oiao F, Cant JP 2006: Prediction of dry matter intake throughout lactation in a dynamic model of dairy cow performance. J Dairy Sci 89: 1558-1570

Frohli DM, Blum JW 1988: Nonesterified fatty acids and glucose in lactating dairy cows: diurnal variations and changes in responsiveness during fasting to epinephrine and effects of beta-adrenergic blockade. J Dairy Sci 71: $1170-1177$

Heinrichs AJ 2013: The Penn State Particle Separator. DSE 2013-186. University of Pennsylvania. Available at: http://extension.psu.edu/animals/dairy/nutrition/forages/forage-quality-physical/separator

Holtenius K, Agenas AS, Delavaud C, Chilliard Y 2003: Effects of feeding intensity during the dry period. 2. Metabolic and hormonal responses. J Dairy Sci 86: 883-891

Hunter RG, Philpot K, Vicentic A, Dominguez G, Hubert GW, Kuhar MJ 2004: CART in feeding and obesity. Trends Endocrinol Metab 15: 454-459

Hwang BH, Guntz JM 1997: Downregulation of corticotropin-relasing factor mRNA, but not vasopressin m RNA, in the paraventricular hypothalamic nucleus of rats following nutritional stress. Brain Res Bull 43: 509-514

Ingvartsen KL, Boisclair YR 2001: Leptin and the regulation of food intake, energy homeostasis and immunity with special focus on periparturient ruminants. Domest Anim Endocrinol 21: 215-250

Janiuk I, Młynek K, Wysocki J 2013: Identification and location of the cocaine and amphetamine regulated transcript (CART) in the abomasum of cattle. Acta Histochem 115: 371-375

Kasacka I, Piotrowska Ż 2012: Evaluation of density and distribution of CART-immunoreactive structures in gastrointestinal tract of hypertensive rats. BioFactors 38: 407-415

Kessel S, Stroehl M, Meyer HHD, Hiss S, Sauerwein H, Schwarz FJ 2008: Individual variability in physiological adaptation to metabolic stress during early lactation in dairy cows kept under equal conditions. J Anim Sci 86: 2903-2912

Koylu EO, Couceyro PR, Lambert PD, Kuhar MJ 1998: Cocaine-and amphetamine-regulated transcript peptide immunohistochemical localization in the rat brain. J Comp Neurol 391: 115-132

Kristensen P, Judge ME, Thim L, Ribel U, Christjansen KN, Wulff BS, Clausen JT, Jensen PB, Madsen OD, Vrang N, Larsen PJ, Hastrup S 1998: Hypothalamic CART is a new anorectic peptide regulated by leptin. Nature 393: 72-76

Leblanc SJ 2010: Monitoring metabolic health of dairy cattle in the transition period. J Reprod Dev 56: 29-35

McGuire MA, Bauman DE, Dwyer DA, Cohick WS 1995: Nutritional modulation of the somatrotropin/insulinlike growth factor system: response to feed deprivation in lactating cows. J Nutr 125: 493-502

Metzner M, Heuwieser W, Klee W 1993: Die Beurteilung der Körperkondition (Body Condition Scoring) im Herdenmanagement (in German). Prakt Tierarzt 11: 991-998 
Młynek K, Janiuk I, Oler A, Maj M, Borkowska L 2015: Correlation between the cocaine- and amphetamineregulated transcript in the pyloric section of the abomasum and fat deposition in bulls' carcasses. Acta Vet Brno 84: $337-342$

Nikkhan A 2011: Bioscience of ruminal intake evolution: feeding time models. Adv Biosci Biotechnol 2: 271-274

Patton J, Kenny DA, McNamara S, Mee JF, O’Mara FP, Diskin MG, Murphy JJ 2007: Relationships among milk production, energy balance, plasma analytics, and reproduction in Holstein-Friesian cows. J Dairy Sci 90: 649-665

Reist M, Erdin DK, Von Euw D, Tschumperlin KM, Leuenberger H, Hammon HM, Morel C, Philipona C, Zbinden Y, Kunzi N, Blum JW 2003: Postpartum reproductive function: association with energy, metabolic and endocrine status in high yielding dairy cows. Therigenology 59: 1707-1723

Roche JR, McDonald KA, Burke CR, Lee JM, Berry DP 2007: Associations among body condition score, body weight and reproductive performance in seasonal calving dairy cattle. J Dairy Sci 90: 376- 391

Samanć H, Kirovski D, Stjić V, Stojanović D, Vujanać I, Prodanović R 2011: Application of the metabolic profile test in the prediction and diagnosis of fatty liver in Holstein cows. Acta Vet-Beograd 61: 543-553

Stengärde L, Tråvén M, Emanuelson U, Holtenius K, Hultgren J, Niskanen R 2008: Metabolic profiles in five high-producing Swedish dairy herds with a history of abomasal displacement and ketosis. Acta Vet Scand 50: 31

Sumner JM, McNamara JP 2007: Expression of lipolytic genes in the adipose tissue of pregnant and lactating Holstein dairy cattle. J Dairy Sci 90: 5237-5246

Vargová M, Petrovič V, Konvičná J, Kadaši M, Zaleha P, Kováč G 2015: Hormonal profile and body condition scoring in dairy cows during pre partum and post partum periods. Acta Vet Brno 84: 141-151

Wang ZW, Zhou YT, Kakuma T, Lee Y, Higa M, Kalra SP, Dube MG, Kalra PS 1999: Unger RH. Comparing the hypothalamic and extrahypothalamic actions of endogenous hyperleptinemia. Proc Natl Acad Sci USA 96: 10373-10378

Wathes DC, Cheng Z, Bourne N, Taylor VJ, Coffey MP, Broyherstone S 2007: Differences between primiparous and multiparous dairy cows in the inter-relationships between metabolic traits, milk yield and body condition score in the periparturient period. Domest Anim Endocrinol 33: 203-225

Wierup N, Gunnarsdóttir A, Ekbald E, Sundler F, 2007: Characterisation of CART-containing neurons and cells in the porcine pancreas, gastro-intestinal tract, adrenal and thyroid glands. BMC Neurosci 8: 51 
Plate IV

Młynek K. et al.: The relationship... pp. 31-38
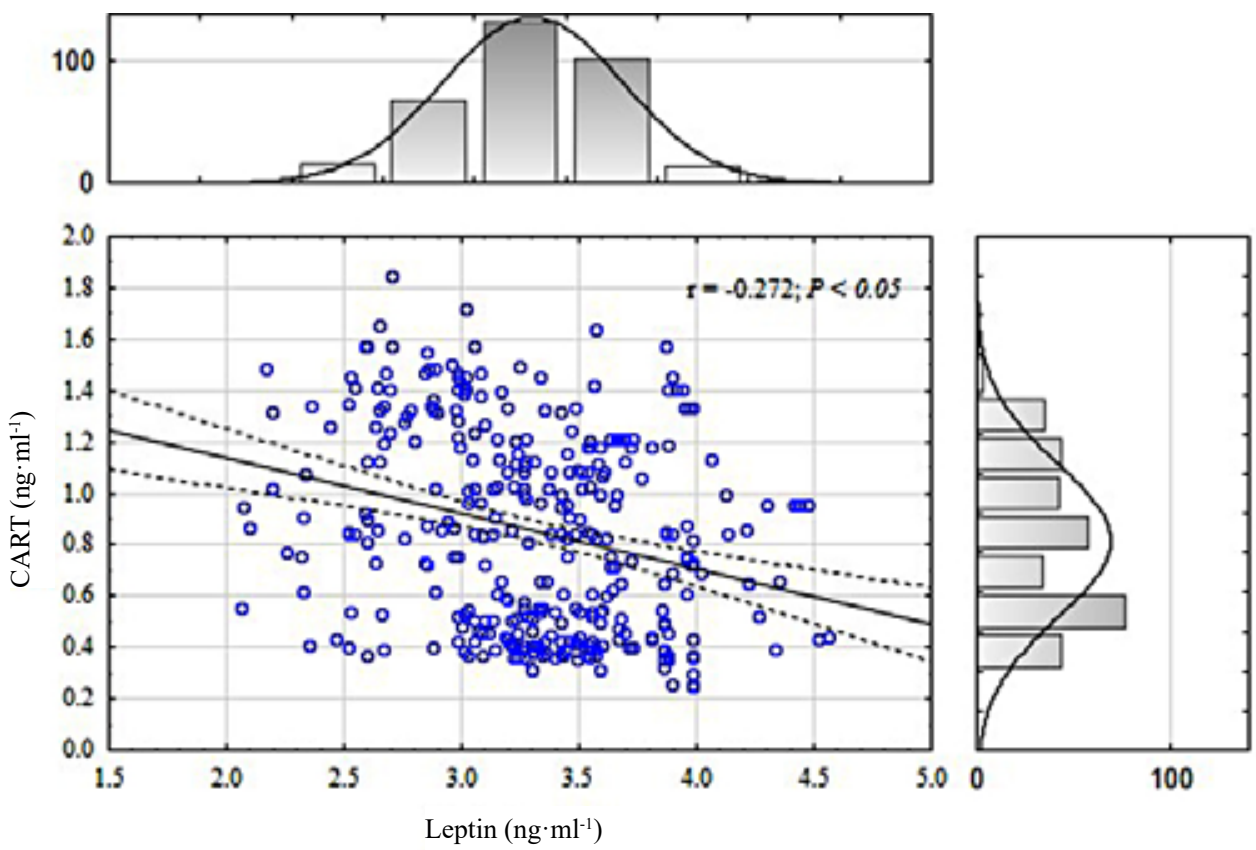

Fig. 1. The correlation coefficient of leptin and cocaine- and amphetamine-regulated transcript (CART) contents and their distribution
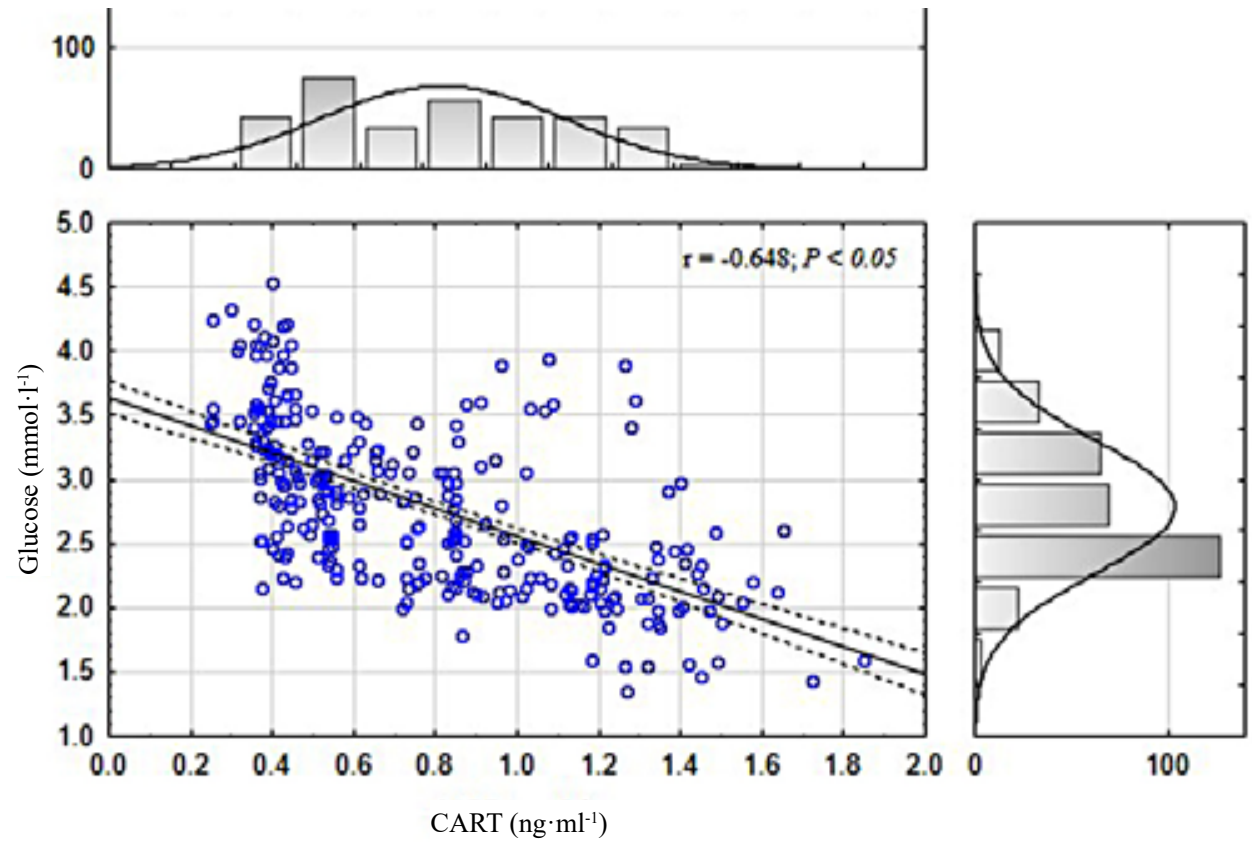

Fig. 2. The correlation coefficient of glucose and cocaine- and amphetamine-regulated transcript (CART) content and their distribution 

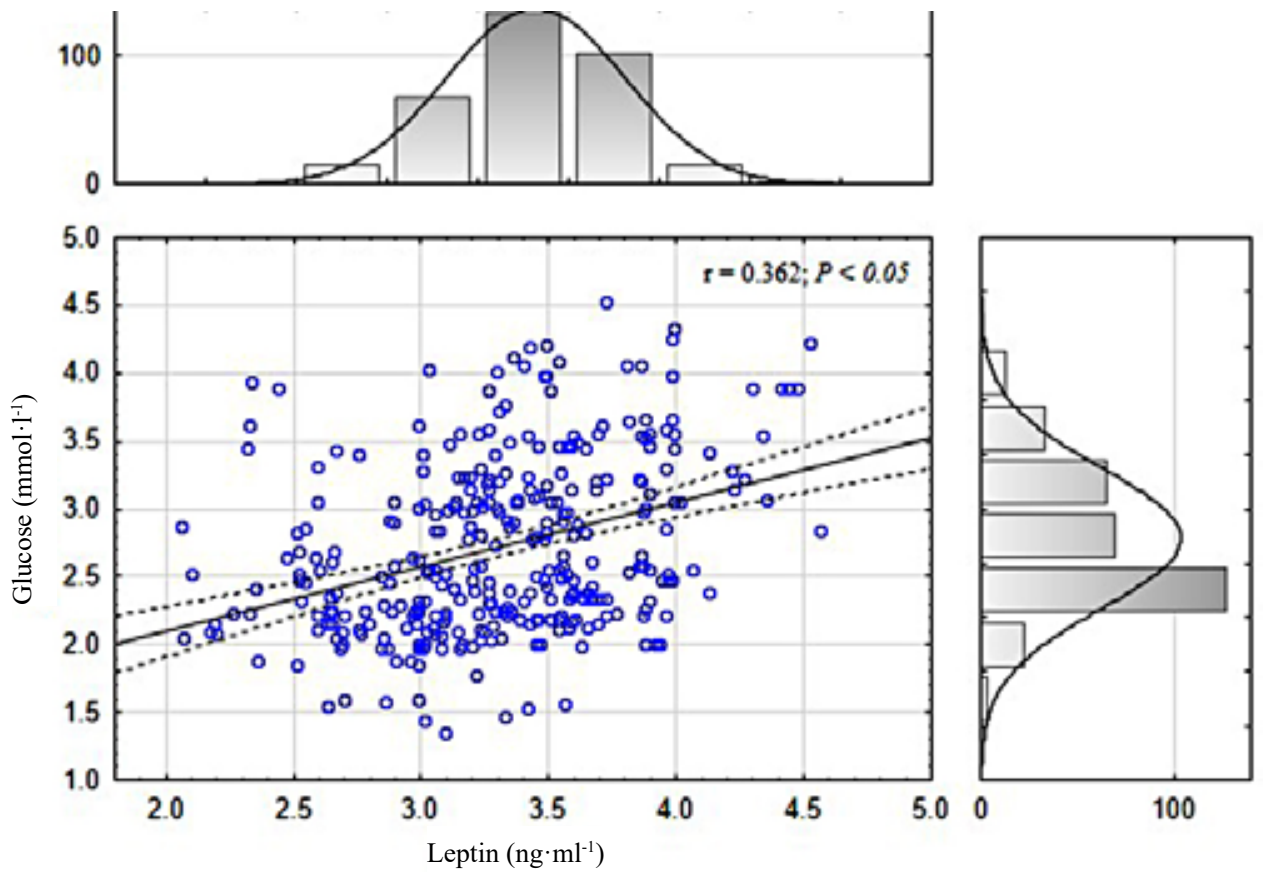

Fig. 3. The correlation coefficient of glucose and leptin content and their distribution 